\title{
PENGARUH MEDIA SOSIAL TERHADAP INTENSITAS HUBUNGAN KOMUNIKASI ORANG TUA DAN ANAK USIA DINI
}

\author{
Marlina ${ }^{1}$ \\ ${ }^{1}$ Universitas Tjut Nyak Dhien, Medan \\ Email: marenzhy@yahoo.co.id
}

\begin{abstract}
Abstrak
Anak adalah aset berharga bagi orang tua, anak akan menjadi cerminan bagaimana orangtuanya sendiri. Pembentukan karakter secara positif pada anak dapat dibangun melalu komunikasi, anak akan merasa nyaman ketika orang tua berposisi sebagai sahabat, karena dapat menunjukan keidealan dalam sebuah hubungan orang tua dan anak. Hubungan yang ideal antara anak dan orang tua secara kasat mata dapat dilihat melalui intensitas komunikasi yang dilakukan oleh orang tua dan anak. Penelitian yang dilakukan dengan cara wawancara mendalam bersama 12 orang ibu serta 3 orang ayah, serta melalui beberapa tahapan pengamatan pada 20 anak dengan rincian, 11 orang laki-laki dan 9 orang perempuan, hasil yang sangat mengejutkan terlihat, bahwa; menunjukan adanya jarak yang tercipta antara orang tua dan anak, ketika orang tua lebih sering memegang alat komunikasi berupa Handphone kemudian terhubung dengan orang lain diluar sana, ketika hal tersebut terjadi maka anak merasa tidak dihargai sampai tingkat pengakuan dari anak tersebut, bahwa mereka ingin sosok orang tua baru, yang dapat mereka ajak bermain sambil bercanda dan memberikan perhatian yang seharusnya.
\end{abstract}

Kata Kunci : Pengaruh Media Sosial, Intensitas Komunikasi, Orang Tua dan Anak Usia Dini.

\section{Pendahuluan}

Anak adalah titipan sekaligus amanah yang harus kita jaga, bukan hanya sekedar menjaganya akan tetapi memberikan hak agar anak tumbuh dengan baik dan maksimal baik secara Psikis maupun Fisik. Semua anak memiliki keunikan masing-masing, dari banyaknya keunikan yang dimiliki oleh setiap anak, mereka memiliki kecendrungan dan kebiasaan yang sama, yaitu butuh perhatian dan kasih sayang. Anak membutuhkan contoh untuk mereka tiru, anak membutuhkan seorang sosok untuk mereka jadikan panutan, semuanya mereka bisa dapatkan seharusnya dari kedua orang tua mereka. Ayah dan ibu memiliki peran penting dalam dua hal tersebut.

Anak sebelum mengenal dunia luar mereka akan selalu mencari kedua orang tuanya saja, mereka merasa tidak ingin pisah sedetikpun dari orang tuanya, dalam hal ini sering kita jumpai adalah ibu, ibu akan senantiasa memiliki pengikut dalam arti ada yang mengikuti kemana saja dia pergi. Anak akan terus mencari jika dia tidak melihat ibunya atau ayahnya walaupun sesaat, anak akan menangis jika dia ditinggal dengan orang yang belum dia kenal, atau jarang mereka lihat. Pada dasarnya ketika anak dibawah usia Lima tahun mereka akan selalu mencari dan mengikuti kedua orang tuanya, terutama ibu. Ibu akan dengan sigap memberikan kenyamanan dalam semua bentuk dan dalam segala aspek bagi sang anak, anak akan diperlakukan bagaikan raja, apa saja keinginan dan kemauan dari anak akan dipenuhi oleh orang tua terutama ibu.

Setiap anak adalah unik, mereka memiliki kemampuan yang berbeda-beda. Menemukan kelebihan dan keunikan seorang anak kemudian dapat mengembangkannya adalah tugas orang tua. Sosok ibu yang sering dekat dengan anaknya akan mampu 
menemukan kelebihan yang dimiliki oleh anaknya tersebut, ibu akan dengan mudahnya menemukan keunikan berupa kelebihan yang dimiliki oleh anaknya melalui berinteraksi secara intens dengan anak. Bermain, bercerita atau hanya sekedar mengamati anak bermain atau melakukan aktifitasnya, kegiatan tersebut adalah cara yang dapat kita lakukan untuk menemukan sejauh mana dan bagaimana sebenarnya keunikan berupa kemampuan dari anak kita tersebut, sehingga orang tua dapat menajamkan kemampuan yang dimiliki oleh anak mereka tersebut.

Diera digital saat ini semua kegiatan dapat dilakukan hanya dengan mengontrolnya melalui jari-jari kita. Kegiatan belanja, belajar memasak seperti membuat kue misalnya, kemudian belajar berdandan atau hanya ingin sekedar mengobrol dengan seseoang yang keberadaannya terlalu jauh dari kita. Kita akan disuguhkan dengan fitur-fitur atau aplikasiaplikasi yang sangat memudahkan keinginan kita untuk terwujud atau kegiatan kita yang mungkin saja tidak bisa kita lakukan dalam satu waktu yang bersamaan. Akan tetapi aplikasi atau fitur yang di tawarkan oleh smartphone dapat menjawab hal tersebut.

Fitur atau aplikasi yang ada dismartphone yang kita miliki sangat mempermudah dan sangat memanjakan, sehingga kita sering terlena dan sedikit enggan untuk keluar walau hanya sekedar membeli makanan atau barang yang lainya. Hadirnya aplikasi ojek online mempermudah pengguna smartphone untuk berbelanja tanpa keluar rumah, atau menggunakan jasa angkutan mereka tanpa harus keluar rumah menunggu angkutan umum atau mengendrai kendraan sendiri. Selain itu kegiatan berkomunikasi juga saat ini telah memanjakan dan menyajikan gaya berkomunikasi baru, tentunya dengan penggunaa media yang didukung dengan sambungan internet.

Komunikasi melalui baru berupa media sosial memberikan warna baru dan pengalaman baru bagi penggunanya, bukan hanya mendekatkan jauh, akan tetapi kita bisa menemukan teman lama yang mungkin saja sudah bertahun-tahun tidak bertemu. Sehingga silaturahmi yang pernah terputus dapat disambung kembali dengan peran media sosial, seperti Facebook, Twitter, Line, Instagram dan lain sebagainya. Tentunya mereka akan menemukan kembali kenangan yang dulu, dan klomunikasi pun berlanjut, dengan berbagai pembahasan dan berita baru dengan menghubungkan kejadian lalu dengan keadaan mereka saat ini.

Pengguna media sosial bukan hanya dilakukan oleh orang dewasa, akan tetapi remaja dan bahkan anak-anak dapat melakukan dan mengoprasikan kegiatan komunikasi melalui media sosial. Dengan aplikasi yang sangat mudah sehingga memungkinkan untuk semua orang dapat mengoprasikannya begitu juga dengan anak-anak. Kemudahan dalam pengoprasiannya membuat media sosial mendapatkan tempat dihati setiap penggunanya. Mereka akan dengan senang hati meluangkan waktu yang mereka miliki hanya sekedar melakukan pengecekan terhadap akun media sosial yang mereka miliki, kemudian akan disibukan dengan kegiatan mengintip status atau profil orang yang mereka anggap menarik untuk selanjutnya dijadikan teman dalam kegiatan dunia maya dengan media sosial tersebut,

Waktu yang mereka miliki hampir tersita secara keseluruhan bergelut dengan media sosial mereka, tak terlepas dengan orang tua, mereka juga memiliki kegiatan yang menurut mereka sangat menyenangkan didunia maya melalui akun media sosial, yang mereka miliki. Tak jarang orang tua terjebak melakukan kegaiatan komunikasi melalui media sosial berjamjam, sehingga mereka lupa dengan kegiatan dunia nyata yang sebenarnya banyak dan menanti dengan rapinya. Waktu yang terpakai dengan begitu saja jarang disadari oleh orang tua, sehingga banyak hal yang terlewatkan oleh mereka. Bagi seorang ibu ada segudang pekerjaan yang menanti, seperti memasak, mencuci dan bermain dengan anak untuk memperhatikan perkembangan dan pertumbuhan anak mereka, serta pemantauan terhadap perubahan sosial yang terjadi pada anak mereka. 
Banyak kegiatan anak luput dari jangkauan orang tua, mereka asik dengan dunia maya melalui media sosial, akan tetapi mereka lupa dengan dunia yang nyata dimana ada beberapa anggota keluarga yang harus mendapatkan perhatian serta perlakuan khusus dari orang tua, dimana seharusnya orang tua baik ibu maupun ayah menjadi contoh, arah serta kontrol terhadap anggota keluarga lainnya, terutama anak yang masih berusia dini. Dalam tulisan ini peneliti menyajikan bagaimana pengaruh media sosial yang dapat memberikan warna baru dari kegiatan berkomunikasi, ternyata memiliki pengaruh yang luar biasa kepada kegiatan berkomunikasi anak dan orang tua.

Anak usia dini sangat membutuhkan perhatian serta teman bermain dan bercerita, orang yang paling dekat atau sahabat yang paling dekat bagi mereka adalah orang tua, anak usia dini tidak sungkan memberikan dan menuangkan semua pendapat dan penilaian mereka kepada orang lain terhadap orang tua mereka. Cerita yang terus mengalir mengenai orang tua mereka tidak dapat direkayasa dan hal tersebut merupakan kebanggan bagi anak usia dini untuk menceritakan orangtuanya yang begiti perhatian pada mereka, bisa kita bayangkan kalau seandainya orang tuanya tidak memberikan apa yang mereka inginkan, seperti waktu dan sebagainya. Apa yang akan menjadi pembahasan mereka kepada orang lain ketika mereka ingin menceritakan kedua orang tuanya.

\section{Kajian teoritis}

Komunikasi merupakan proses yang terus menerus dan dinamis. Komunikasi berasal dari bahasa Latin, communicare artinya berbicara, menyampaikan pesan, informasi, pikiran, perasaan, gagasan, dan pendapat yang dilakukan oleh seseorang kepada orang lain dengan mengharapkan jawaban atau feedback. Dapat pula diartikan sebagai pemberitahuan, pemberian bagian dalam pertukaran, atau pidato yang oleh pembicara dimintakan pertimbangan para pendengar. Communicare berarti juga dua orang atau lebih (baca komunikasi interpersonal), atau sistem, bertindak bersama, bertemu, berada bersama-sama baik secara langsung (tatap muka), maupun melalui media tertentu. ${ }^{1}$

Komunikasi interpersonal merupakan proses komunikasi yang berlangsung antara dua orang atau lebih secara tatap muka ${ }^{2}$ dengan menggunakan simbol tertentu yang disepakati. Istilah lain yang populer adalah komunikasi diadik, faktanya bahwa komunikasi interpersonal merupakan suatu ajang yang paling sering terjadi dalam kehidupan manusia, walaupun dalam wadah yang lebih besar seperti kelompok dan organisasi. Komunikasi menciptakan kehadiran atau keberadaan bersama. Manusia tidak bisa menolak kehadiran orang lain. Implikasi kebersamaan dan kehadiran bersama adalah terciptanya masyarakat. ${ }^{3}$

Perilaku komunikasi menggambarkan kepribadian para pelakunya, dan pada saat yang sama komunikasi antarmanusia juga dapat memengaruhi kepribadian seseorang. Beberapa riset komunikasi memperlihatkan indikasi adanya korelasi yang kuat antara perilaku komunikasi dengan kepribadian pelakunya. Melalui komunikasi, seseorang akan mengenal karakteristik perilaku, baik dirinya maupun orang lain yang berada pada ruang publik yang sama. Aktivitas komunikasi ini akan dapat menjalin relasi dengan sesama dan menumbuhkan kesadaran bahwa manusia adalah makhluk sosial, yang tidak mungkin diisolasi dari kehidupan dengan sesamanya. ${ }^{4}$

Sehingga dapat dikatakan, bahwa tidak ada komunikasi tanpa interaksi. Interaksi dan komunikasi merupakan dua proses yang dilalui oleh setiap makhluk manusia sebagai akibat dari dimensi sosial yang diberikan Tuhan. Itulah sebabnya, komunikasi merupakan bagian substansial dari aktivitas manusia yang dapat memberikan kontribusi penting dalam proses

\footnotetext{
${ }^{1}$ Muis, Komunikasi Islami, h. 36-37.

${ }^{2}$ Hafied Changara, Pengantar Ilmu Komunikasi (Jakarta: Rajawali Press, 2006), h. 31.

${ }^{3}$ Muis, Komunikasi Islami, h. 38.

${ }^{4}$ Muhtadi, Komunikasi, h. 159.
} 
memanusiakan manusia ${ }^{5}$ - keseimbangan antara dimensi nasut dan lahut, humanisme dan spiritual. Intensitas komunikasi seseorang akan berkorelasi secara positif dengan kesadaran individu dalam kaitannya dengan orang lain. Rasa empati misalnya, akan tumbuh melalui aktivitas mengenal dirinya dengan bercermin pada orang lain.

Harnack dan Fest menganggap komunikasi sebagai proses interaksi di antara orang untuk tujuan integrasi intrapersonal dan interpersonal serta berfungsi untuk mengubah kelompok manusia menjadi kelompok yang berfungsi. Komunikasi merupakan peristiwa sosial-peristiwa yang terjadi ketika manusia berinteraksi dengan manusia lain sehingga secara perlahan terbentuklah kepribadiaan. Bagaimana seseorang menafsirkan pesan yang disampaikan orang lain dan bagaimana pula sebaliknya, seseorang menyampaikan pesannya kepada orang lainnya, akan menentukan kepribadiannya. Kepribadian terbentuk sepanjang hidup manusia. Selama itu pula, komunikasi menjadi penting untuk pertumbuhan pribadi seseorang. Melalui komunikasi, manusia menemukan dirinya, mengembangkan konsep diri, dan menetapkan hubungan seseorang dengan dunia di sekitarnya. Hubungan manusia dengan orang lain akan menentukan kualitas hidupnya. ${ }^{6}$

Media sosial merupakan media baru yang "merasuki" pemikiran dan prilaku si pengguna, banyak yang hanyut kedunia maya karena menemukan keasikan tersendiri ketika mereka berada didalamnya, yang kesemuanya itu adanya dan disediakan dalam bentuk media sosial, yang mana media sosial dapat menjadi wadah ekspresi diri dan mendapatkan pengakuan dari pengguna media sosial lain yang selanjutnya bisa disebut sebagai masyarakat dunia maya.

Media sosial memiliki perbedaan dan spesifikasi tersendiri dibanding dengan media cetak, audio visual dan lainnya, karakteristik juga merupakan ciri khas yang tidak dimiliki oleh media lain, atau sebuah kekhususan yang menguatkan ciri atau pembeda antara media sosial dengan media lain yang ada. Karakteristik yang dimiliki oleh media sosial setidaknya dapat menggambarkan kehususan terhadap media tersebut, paling tidak ada enam poin yang menjadi karakteristik dari media sosial selain karakreristik dapat juga disebut sebagai ciri-ciri dari media sosial tersebut, adapun karakteristik tersebut adalah; Jaringan (network), Informasi (Information), Arsip (Archive), interaksi (Interactivity), simulasi sosial (simulation of society), konten oleh pengguna (User-Generated content). ${ }^{7}$ Media baru (new media) adalah sebuah terminologi untuk menjelaskan konvergensi antara teknologi komunikasi digital yang terkomputerisasi serta terhubung ke dalam jaringan. Media baru adalah segala sesuatu yang dapat menyalurkan informasi (perantara) dari sumber informasi kepada penerima informasi. "Media baru memiliki dua unsur utama yakni digitalisasi dan konvergensi. Internet merupakan bukti konvergensi karena menggabungkan beberapa fungsi media lain seperti audio, video, dan teks“".

Meskipun karakteristik media sosial dapat dilihat melalui media siber, akan tetapi media sosial memiliki ciri khas yang tidak dimiliki oleh media siber lainnya. Ada batasanbatasan dan ciri khusus tertentu yang dimiliki oleh media sosial akan tetapi tidak dimiliki oleh media lainnya, yaitu bagaimana media sosial itu berubah fungsi menjadi sarana sosial di dunia virtual ${ }^{8}$, bukan berarti tidak ada ada ciri atau karakter secara umum, hanya saja pembahasan karakteristik media sosial ini dipandang sangat penting, untuk membedakan mana media sosial dan media lainnya. Keenam poin yang disebutkan diatas tersebut merupakan ciri dan menunjukan kekhususan yang dimiliki oleh media sosial dan menunjukan pembeda media sosial dengan media yang lain dengan akses yang sama yaitu dengan akses

\footnotetext{
${ }^{5}$ Ibid.

${ }^{6}$ Lihat Rakhmat, Psikologi, h. 8-13.

7 Ruli Nasrullah, media sosial persfektif komunikasi, budaya dan sosiotekhnologi. (bandung: simbiosa rekatama media, 2015). h,16

${ }^{8}$ Ibid. h, 15
} 
internet. Banyak media lain yang memilki pengaksesan yang sama yaitu dengan akses jaringan internet, akan tetapi kekhususan nya hampir tidak kita jumpai di media berbasis internet lainnya.

Media sosial memberikan kemudahan bagi penggunanya, selain kemudahan media sosial juga memberikan bentuk dunia baru kepada pengguna media tersebut. Kemudahan dan dunia baru tersebut ternyata memiliki dampak bagi kegiatan komunikasi langsung yang dilakukan oleh masyarakat seperti biasanya, yang sering kita kenal dengan komunikasi langsung melalui tatap muka. Meskipun begitu penggunan media sosial tidak luput dari keseharian penggunanya, karena media sosial memberikan dunia baru dan "candu" yang sangat susah untuk dilepaskan.

\section{Metodologi}

Penelitian ini adalah penelitian kualitatif, yang sering disamakan pengertiannya dengan penelitian naturalistik yang berusaha memahami bagaimana orang-orang mempersepsi dunia dengan menelaah bagaimana mereka berkomunikasi. ${ }^{9}$ Penelitian kualitatif yaitu suatu penelitian kontekstual yang menjadikan manusia sebagai instrumen, dan disesuaikan dengan situasi yang wajar dalam kaitannya dengan pengumpulan data yang pada umumnya bersifat kualitatif. Menurut Bogdan dan Taylor penelitian kualitatif merupakan prosedur penelitian yang menghasilkan data deskriptif berupa kata-kata tertulis atau lisan dari orang-orang dan perilaku yang dapat diamati. ${ }^{10}$

Pendekatan kualitatif dicirikan oleh tujuan penelitian yang berupaya memahami gejala-gejala yang sedemikian rupa yang tidak memerlukan kuantifikasi, karena gejala tidak memungkinkan untuk diukur secara tepat. ${ }^{11}$ Selanjutnya metode kualitatif ini mempunyai beberapa cara yang disesuaikan dengan kebutuhan-kebutuhan data yang diperlukan. Mulyana menyebutkan bahwa, metode penelitian kualitatif dilakukan dengan cara deskriptif (wawancara tak berstruktur/wawancara mendalam, pengamatan berperan serta), analisis dokumen, studi kasus, studi historis kritis; penafsiran sangat ditekankan alih-alih pengamatan objektif. $^{12}$

Penelitian deskriptif ini akan memaparkan permasalahan dalam sebuah peristiwa, dalam penelitian ini tidak membahas atau membuat prediksi terhadap sebuah persitiwa berdasarkan hipotesis. ${ }^{13}$ Dalam penelitian ini peneliti akan mencoba untuk menghubungkan antara data yang diterima dengan teori yang digunakan, sehingga ada hasil yang merujuk pada sebuah kesimpulan nantinya. Melibatkan beberapa orang responden untuk dimintai keterangan melalui wawancara yang dilakukan secara terbuka, akan tetapi mengarah kepada wawancara mendalam, responden diusahakan tidak terbebani atas setiap pertanyaan. ${ }^{14}$ Pertanyaan-pertanyaan tadi sebenarnya merupakan inti dari permasalahan yang ingin diketahui oleh peneliti.

Penelitian dilakukan dengan cara wawancara mendalam ini melibatkan 12 orang ibu serta 3 orang ayah, untuk jawaban dari orang tua maka peneliti melakukan menyempurnakan

\footnotetext{
${ }^{9}$ Deddy Mulyana, Metodologi Penelitian Kualitatif: Paradigma Baru Ilmu Komunikasi dan Ilmu Sosial Lainnya (Bandung: PT. Remaja Rosdakarya, 2003), h. 157-158. Bandingkan dengan Suwardi Endraswara, Metode, Teori, Teknik Penelitian Kebudayaan: Ideologi, Epistemologi, dan Aplikasi (Yogyakarta: Pustaka Widyatama, 2006), h. 62-64.

${ }^{10}$ Lexy J. Moleong, Metodologi Penelitian Kualitatif (Bandung: PT. Remaja Rosdakarya, 2000), h. 3.

${ }^{11}$ Judistira K. Garna, Teori-Teori Perubahan Sosial (Bandung: Program Pascasarjana Universitas Padjadjaran, 1991), h. 32.

${ }^{12}$ Mulyana, Metodologi, h. 148.

${ }^{13}$ Jalaluddin Rakhmat, 2004. Metode Penelitian Komunikasi. Remaja Rosda Karya. Bandung. hal,24-26

${ }^{14}$ Ibid, $h 25$
} 
sumber data melalui pengamatan pada 20 anak dengan rincian, 11 orang laki-laki dan 9 orang perempuan. Pertanyaan yang sama akan dilontarkan kepada orang tua sebagai responden yang mengarah kepada inti dari penelitian ini yaitu seberapa seringkah mereka mengamati smartphone bila dibandingkan berbicara dengan anak mereka.

Pengamatan kepada anak dilakukan dengan cara melihat keterampilan anak dalam bergaul dengan sesama anak, bagaimana mereka memperlakukan teman, kemudian apakah mereka mau berbagi mainan dengan teman mereka, selain itu apakah ada dalam pergaulannya dengan teman sebaya si anak membahas atau menceritakan mengenai kegiatan keseharian mereka dirumah.

\section{Pembahasan}

Anak merupakan sumberdaya manusia dianugerahkan oleh Tuhan yang Maha Esa membutuhkan perhatian orang dewasa ${ }^{15}$. Anak merupakan generasi penerus keluarga sehingga perlu dipersiapkan sejak dini agar kelak menjadi manusia yang berkualitas sesuai dengan kesepakatan cita-cita bangsa. Interaksi antara orangtua dan anak sangat menentukan dasar pembekalan pada seorang anak. Agar proses tumbuh kembang anak terjamin dan berlangsung secara optimal. Kebutuhan dasar anak di tingkat keluarga harus terpenuhi. Kebutuhan dasar tersebut meliputi kebutuhan akan perhatian dan kasih sayang orangtua maupun anggota keluarga lainnya. Lingkungan pertama dan utama yang dapat mengarahkan seorang anak untuk menghadapi kehidupannya adalah keluarga. Melalui keluarga, anak dibimbing untuk mengembangkan kemampuan dan kreativitasnya serta menyimak nilai-nilai sosial yang berlaku. Keluarga pulalah yang memperkenalkan anak kepada lingkungan yang lebih luas, dan di tangan keluargalah anak dipersiapkan untuk menghadapi masa depannya dengan segala kemungkinan yang timbul.

Penggunaan media sosial dikalangan masyarakat indonesia khususnya para orang tua sudah menjadi kebiasaan baru yang sangat lekat, setiap hari paling tidak mereka akan membuka Smartphone mereka untuk sekedar melihat dunia baru mereka atau bahkan berusaha untuk berkomunikasi dengan dunia baru yang diciptakan melalui media sosial. Dunia baru yang tercipta dari kegiatan komunikasi dimedia sosial memiliki sisi yang dapat mengubah seseorang. Kemajuan dunia dan berita apapun dapat kita peroleh dengan cepat dengan menggunakan media sosial. Media sosial bagaikan mata uang dengan dua sisi yang tidak bisa dipisahkan dari kebutuhan manusia.

Kebiasaan pengguna media sosial sangat berbeda, dari 20 orang yang menjadi responden mereka memiliki kebiasaan yang berbeda mengenai kebiasaan pengguna media sosial tersebut, selain menjadi kebiasaan mereka juga memiliki tujuan yang berbeda dalam penggunaan media sosial. Ada yang memiliki tujuan mencari teman lama, ingin sekedar eksis atau bahkan menjadikan media sosial sebagai media dalam melakukan transatujuan penggunaan media sosial dari responden pada umumnya adalah untuk membangun komunikasi dengan kerabat atau teman lama yang terpisah jarak yang cukup jauh untuk melakukan komunikasi tatap muka secara langsung.

Melakukan komunikasi melalui media sosial sangatlah menyenangkan dan memiliki daya tarik luar biasa. Banyak hal positif yang disajikan dari media yang berbasis internet tersebut. Akan tetapi dari sekian banyak hal positif yang bisa diambil, akan dampak negatif yang di timbulkan dalam pengguna media sosial juga sangat beragam, salah satunya adalah berkurangnya kegiatan komunikasi tatap muka secara langsung dilakukan.

Hubungan komunikasi yang dilakukan dimedia sosial memiliki sisi negatif, mulai dari berkurangnya intensitas komunikasi yang dilakukan oleh orang tua dan anak, sesama pasangan sampai dengan tindakan kriminal dan kejahatan dapat ditimbulkan dari kegiatan

${ }^{15}$ Jenifer Fox. Keunggulan dan kelebihan anak anda. Indeks. Jakarta. 2011. h 9 
berkomunikasi dimedia sosial. Sisi negatif dari kegiatan komunikasi melalui media sosial yang sudah di jelaskan diatas adalah berkurangnya intensitas komunikasi tatap muka langsung yang dilakukan oleh orang tua dan anak. Orang tua sangat terbuai dengan dunia baru mereka yang difasilitasi oleh media sosial.

Perkembangan dan pertumbuhan anak mulai sejak bayi, anak-anak, remaja hingga dewasa tak lepas dari peran keluarga sebagai patron dan contoh awalnya. Keluarga memiliki peran utama dalam membentuk karakter anak karena keluarga terutama ibu adalah madrasah pertama yang dijumpai anak sehingga perkembangan dan pertumbuhan anak akan menggambarkan keadaan dan kondisi keluarga saat itu. Bila keluarga baik maka anak akan bertumbuh menjadi pribadi yang baik pula, akan tetapi bila di keluarga anak tidak mendapatkan perhatian yang baik, perlakuan yang baik, maka anak akan tumbuh sebaliknya.

Komunikasi adalah proses penyampain pesan dengan perantara media ataupun langsung, kemudian memiliki pesan yang nantinya akan mengubah prilaku atu sikap penerima pesan sesuai dengan isi pesan yang disampaikan. Ketika adanya perubahan dari satu sikap kesikap yang diinginkan oleh pemberi informasi, maka komunikasi tersebut dikatakan efektif dan berhasil. Pada intinya tujuan berkomunikasinya seseorang adalah untuk mengubah sikap, prilaku dan tindakan seseorang kepada satu bentuk prilaku yang diinginkan oleh yang menyampaikan pesan.

Melalui pengamatan dari 20 orang anak yang menjadi responden peneliti, hanya 7 orang anak saja yang melakukan kegiatan komunikasi dengan interaktif serta daya kreatif tinngi, hal ini disebabkan adanya intensitas komunikasi serta perhatian dari orangtua ketika mereka berada dirumah, selain itu komunikasi yang dilakukan oleh orang tua 7 anak tersebut terbilang bersahabat dan sesuai dengan apa yang diinginkan oleh anak-anak pada umumnya, seperti diperhatikan ketika bercerita, kemudian dihargai ketika mereka sedang mengutarakan apa yang ingin mereka sampaikan dan apa yang menajdi perasaan mereka saat itu.

Hubungan yang positif akan menghasilkan perbuatan yang positif pula, anak yang mendapatkan sambutan yang hangat dan positif dari orang tua mereka akan menularkan hal yang serupa kepada teman-temannya, anak akan merasa dihargai sehingga anak akan melakukan kegiatan yang positif kepada teman-teman sebayanya dan lingkungan sekitarnya. Anak yang memiliki kegiatan komunikasi yang intens terhadap orangtuanya tanpa diganggu dengan penggunaan Smartphone dari orang tuanya, terlihat lebih leluasa ketika melakukan kegiatan komunikasi dengan teman yang lain. Anak akan merasa senang dan bahagia ketika mereka dimintai bercerita dengan yang lain mengenai orang tua mereka.

9 anak bersikap lebih reaktif, agak sedikit kasar bila ada yang berkata dengan nada yang lebih tinggi maka mereka akan menunjukan reaksi yang sedikit negatif, ada yang melawannya denga kata-kata kasar bahkan ada yang memukul. Komunikasi dengan teman sebaya juga tidak berlangsung secara positif biasanya mereka akan melakukan perbuatan yang mengarah kepada pemaksaaan, merebut makanan atau mainan, dan yang paling sangat ditakuti oleh orang tua adalah mengambil tanpa izi atau dengan kata lainnya mencuri. Ketika di tanya mengapa mereka melakukan.

Pengamatan dilanjutkan keapada wawancara dengan orang tua yang memiliki reaksi anak reaktif dan sedikit memaksa. Orang tua sangat memanjakan dan memberikan kebeasan yang lebh leluasa kepada anak, seperti memberikan uang jajan yang berlebih ketika anak mulai merengek. Hal tersebut diatas diakui oleh sebahagian besar orang tua dilakukan ketika anak mulai menggangu jam santai orang tua, dan orang tua biasanya ketika jam santai mereka melakukan komunikasi atau aktifitas dengan dunia maya. Sehingga anak akan beusaha dibujuk dengan memberikan sesuatu yang sangat disenangi oleh anak mereka ketika mereka mulai rewel mulai dari membiarkan main Smartphone yang sengaja disiapkan sampai memberikan uang agar anak mereka bisa membeli cemilan sendiri, tentunya tanpa pengawasan orang tua. 
Komunikasi yang efektif adalah komunikasi yang dilakukan dari hati ketika komunikasi terhambat, akan banyak permasalahan yang akan timbul. Begitu juga dengan komunikasi yang kita lakukan secara intesnatau berkesinambungan dengan orang lain, komunikasi akan menimbulkan efek yang sangat luar biasa. Berbicara mengenai komunikasi yang dilakukan dengan media sosial adalah sebuah hal kemajuan dalam kegiatan berkomunikasi, inovasi dalam kegiatan berkomunikasi merupakan sesuatu yang tidak bisa kita hindari, karena saat ini merupakan era tekhnologi digital. Kegiatan komunikasi kerap memiliki efek atau dampak terhadap siapa saja yang ikut terlibat dalam proses kegiatan komunikasi tersebut, selain efek komunikasi juga memiliki konsekuensi. ${ }^{16}$

Penggunaan media sosial dalam berkomunikasi sering sekali memiliki dampak negatif terhadap komunikasi tatap muka langsung. Seorang anak akan merasa tidak diperhatikan oleh orang tua ketika orang tua sedang asik dengan dunia mayanya melalui media sosial. Pembiaran tersebut akan berlangsung terus menerus sehingga membuat anak merasa terasingkan dan anak akan mencari perhatian dalam bentuk tingkah laku yang berbeda, seperti lebih sedikit nakal, sering mengamuk, dan tingkah laku yang dapat menarik perhatian orang tua mereka. Anak akan cenderung sedikit susah diatur, karena mereka akan merasa mendapatkan perhatian dengan berlaku sedikit nyeleneh atau sedikit nakal. Hal tersebut terjadi karena orangtuanya mereka anggap lebih sayang dengan Smartphone mereka daripada dengan anaknya, begitulah anggapan anak-anak ketika melihat orang tuanya lebih sering memperdulikan Smartphone dari pada anak mereka. Ketika Smartphone mereka mati, orang tua akan segera mencharge Smartphone tersebut, akan tetapi ketika anak menangis atau mau minta makan atau hanya nsekedar ingin bercerita, orang tua akan menjawab atau meminta anak untuk bersabar menunggu orangtuanya menyelesaikan pekerjaan mereka dengan Smartphon yang tetap lekat ditangan.

Iklan Televisi yang menayangkan adanya keinginan seorang anak TK menjadi sebuah Smartphone bukanlah sebuah cerita berlebihan, karena kecanduan dalam melakoni dunia maya melalu media sosial mereka telah mencuri perhatian dan kasih sayang orang tua yang seharusnya anak dapati, kenyataannya orang tua tidak akan mau berpisah jauh dari Smartphone mereka, karena melalui Smartphone mereka mendapatkan dunia baru yang disana mereka dapat mendapatkan pengakuan dan bisa mengekspresikan diri dalam bentuk dan gaya yang mereka inginkan yang dengan cara berkomunikasi tatap muka langsung sangat sulit untuk mereka lakukan.

Berkomunikasi secara langsung denga tatap muka dapat merasakan apa yang tidak dikatakan oleh lawan bicara dengan kata-kata, karena berkomunikasi secara langsung adalah komunikasi kontak mata dan komunikasi yang sebenarnya, berbeda dengan komunikasi yang dilakukan melalui media sosial yang penuh dengan pembenaran atas ketidak benaran serta keadaan yang banyak tidak sesuai dengan realita sebenarnya. Setiap kegiatan Komunikasi pastinya memiliki tujuan dan motif. Pemberitahuan atas motif dan tujuan dari sebuah kegiatan komunikasi tidak perlu untuk dikemukakan secara gamblang. Karena seiring dengan proses kegiatan komunikasi tersebut tujuan dan motif komunikasi akan terungkap dengan sendirinya ${ }^{17}$.

Tujuan dan motif komunikasi tidak akan melenceng dari isi pesan yang disampaikan oleh komunikator, meskipun melalui media sosial dengan kecanggihan fitur yang ditawarkan oleh aplikasi tersebut. Tujuan komunikasi adalah untuk membentuk sikap dan pemikiran atas setiap pesan yang kita sampaikan kepada seseorang, selain tujuan efek komunikasi juga merupakan sesuatu hal yang perlu diperhatikan, karena efek yang diinginan merupakan satu kesatuan yang ditimbulkan dari kegiatan berkomunikasi. Efek berkomunikasi

\footnotetext{
${ }^{16}$ Joseph A.Devito. Komunikasi Antarmanusia, Remaja Rosda Karya. Bandung. 2007. h 28

17 Ibid, hh 30
} 
salah satunya adalah mendekatkan pribadi dan menyamakan fisi yang tidak secara tersurat saat berkomunikasi, akan tetapi kesaaman yang dimaksud dapat membentuk sikap lawan bicara. Begitu juga dengan komunikasi dengan anak, dapat membentuk karakter dan sikap positif dari anak sesuai dengan apa yang diinginkan oleh orang tuanya.

Setiap orang tua akan memberikan nilai positif serta hal-hal positif kepada anaknya, agar mereka memiliki karakter positif serta memiliki akhlakul karimah, yang nanti ketika mereka beranjak remaja, dewasa bahkan ketika mereka akan berkeluarga dapat memiliki pegangan positif untuk meneruskan kepada generasi selanjutnya. Bila saja komunikasi yang dibangun tidak dirusak dan dirasuki oleh kegiatan atau pengaruh yang berasal dari media sosial yang belum tentu memiliki nilai positif dan membangun bagi penggunanya. Keintensitasan komunikasi anak usia dini sangat memberi dampak pada kehidupan mereka kedepannya nanti, karena anak usia dini ibarat sebuah embor kosong yang siap meneriama apa saja yang diisikan kedalamnya. Hal positif akan menghasilkan sesuatu yang positif juga, semua tergantung orangtua yang menginginkan anak mereka kedepan menjadi apa dan bagaimana, anak yang kita bentuk akan menjadi penerus generi bangsa kedepan nantinya.

\section{Kesimpulan}

Kemajuan dan kecangihan tekhnologi dewasa ini sangat memudahkan bagi manusia, pekerjaan yang membutuhkan waktu dan tenaga lebih besar dapat diselesaikan dengan solusi dari kecanggihan tekhnologi. Keberadaan media sosial salah satunya, dengan memiliki akun dimedia sosial sangat membantu untuk menemukan kembali saudara, kerabat serta teman yang sudah lama tidak bertemu atau memiliki jarak yang sangat jauh untuk dikunjungi daqpat kembali terjalin dengan kemudahan yang ditawarkan oleh media sosial. Kemajuan tekhnologi yang ditawarkan melalu media sosial yang berbasi internet ini sangat memberikan warna baru dalam kegiatan komunikasi yang dilakukan penggunanya.

Dunia maya adalah hasil dari interaksi yang dilakukan oleh para pengguna media sosial, kemudahan dan keunikan berkomunikasi dimedia sosial tidak seperti didunia nyata. Komunkasi melalui media sosial memberikan ruang kepada penggunanya untuk menjadikan diri mereka diakui ddunia maya dan hal ini terkadang bertolak belakang dengan kegiatan komunikasi yang dilakukan dengan cara tatap muka langsung. Melakukan komunikasi dengan media sosial memang memberikan warna yang berbeda, akan tetapi bukan hanya warna yang berbeda yang ditimbulaknnya, efek lain juga akan timbul seperti pembiaran dengan dunia nyata yang mengakibatakan berkurangnya kegiatan komunikasi langsung secara tatap muka oleh pengguna media sosial tersebut.

Dampak yang ditimbulkan dari komunikasi didunia maya adalah tidak peduli dengan lingkungan sekitarnya. Khususnya untuk orang tua akan lebih membiarkan anak mereka khususnya anak dengan usia dini, dimana anak dengan usia dini ini memerlukan komunikasi tatap muka langsung dengan orang tuanya. Bila orang tua tidak memperhatikan dan memberikan waktu kepada anak mereka banyak akan menimbulkan permaslahan dan pemnbentuka karakter yang keras kepala untuk anak mereka dikemudian hari nantinya. Karena anak usia dini menganggap orangtuanya adalah segalanya bagi mereka. Anak akan mengidolakan orang tuanya dalam segala hal. Dampak lain adalah berkurangnya intensitas komunikasi tatap muka langsung oleh orang tua dengan anak usia dini mereka, ibu dan ayah yang telah ytersita waktunya dan telah candu dengan media sosial secara tidak sadar sudah membangun sekat berupa tembok yang kokoh untuk hubungan anak dan orang tua, anak akan berusaha menuangkan kerinduan dan haus perhatiannya dengan melakukan hal yang anehaneh. 


\section{Daftar pustaka}

Andi Abdul Muis, Komunikasi Islami. Bandung: PT. Remaja Rosdakarya, 2001

Hafied Changara, Pengantar Ilmu Komunikasi. Jakarta: Rajawali Press, 2006.

Jalaludin Rakhmat, Psikologi Komunikasi, Bandung, PT.Remaja Rosda Karya, 2007

Ruli Nasrullah, media sosial persfektif komunikasi, budaya dan sosiotekhnologi. bandung: simbiosa rekatama media, 2015

Deddy Mulyana, Metodologi Penelitian Kualitatif: Paradigma Baru Ilmu Komunikasi dan Ilmu Sosial Lainnya, Bandung: PT. Remaja Rosdakarya, 2003

Suwardi Endraswara, Metode, Teori, Teknik Penelitian Kebudayaan: Ideologi, Epistemologi, dan Aplikasi, Yogyakarta: Pustaka Widyatama, 2006

Lexy J. Moleong, Metodologi Penelitian Kualitatif (Bandung: PT. Remaja Rosdakarya, 2000

Judistira K. Garna, Teori-Teori Perubahan Sosial, Bandung: Program Pascasarjana Universitas Padjadjaran, 1991

Jenifer Fox. Keunggulan dan kelebihan anak anda. Indeks. Jakarta. 2011.

Joseph A.Devito. Komunikasi Antarmanusia, Remaja Rosda Karya. Bandung. 2007 